Samaranayake, R.A.D.I.U., Jayawickrama, T.S., Melagoda, D.G. and Rathnayake, R.M.D.I.M., 2019. Decision making on adaptive reuse of historic buildings in Sri Lanka. In: Sandanayake, Y.G., Gunatilake, S. and Waidyasekara, A. (eds). Proceedings of the $8^{\text {th }}$ World Construction Symposium, Colombo, Sri Lanka, 8-10 November 2019, pp. 239-247. DOI: doi.org/10.31705/WCS.2019.24. Available at: https://2019.ciobwcs.com/papers

\title{
DECISION MAKING ON ADAPTIVE REUSE OF HISTORIC BUILDINGS IN SRI LANKA
}

\author{
R.A.D.I.U. Samaranayake ${ }^{1}$, T.S. Jayawickrama ${ }^{2}$, D.G. Melagoda ${ }^{3}$ and \\ R.M.D.I.M. Rathnayake ${ }^{4}$
}

\begin{abstract}
The construction industry is consistently involved with improving the economic, social and environmental parameters of sustainability. This has led the sustainability in construction to shift from an original focus on cleaner and leaner project delivery to a restorative and regenerative approach. Increasing demand for urban regeneration has driven the act of preserving and reusing parts of cities with historical significance for a variety of uses. Thereby, adaptive reuse serves as an attractive and superior alternative for reusing buildings with architectural and historical importance in terms of sustainability and a circular economy. However, many historic buildings are being disused or demolished due to the inability of determining viable new uses for historic buildings. Thus, this study aimed at providing systematic guidance for decision-making on Adaptive Reuse of Historic Buildings (ARHB) in Sri Lanka. A comprehensive literature review was conducted to explore the concept of adaptive reuse, related regulations, drivers and barriers, new uses for historic buildings and factors affecting decision-making on adaptive reuse of buildings. Finally, this paper proposes a conceptual framework to assist decision making on ARHB in Sri Lanka.
\end{abstract}

Keywords: Adaptive Reuse; Decision-making; Historic Buildings; New Uses.

\section{INTRODUCTION}

According to Dean et al. (2016), buildings are responsible for more than $30 \%$ of global energy use and represent more than one third of global final energy consumption while contributing to nearly one quarter of greenhouse gas emissions worldwide. Hence, the built environment has a prominent role to play in minimizing the overall carbon emissions, particularly as it demands $40 \%$ of global resources and generates a proportionate amount of waste (Langston, 2008). In this vein, Conejos et al. (2015) suggest that the concept of adaptive reuse is rapidly gaining global recognition as an effective strategy to improve the built environment sustainability. Historic buildings constitute a higher portion of the overall building stock in the world, making it impossible to preserve them all intact (Yung and Chan, 2012). As the paradigm in conservation has changed from preserving something from the past to utilize the past in the present, adaptive reuse can be distinguished as an important conservation intercession to recycle the past resources and transform them into experiences in and for the present (Ashworth, 2011). Internationally many researches (Ball, 1989, 2002; Bullen, 2007; Langston and

\footnotetext{
${ }^{1}$ Department of Building Economics, University of Moratuwa, Sri Lanka, imanthasam@gmail.com

${ }^{2}$ Department of Building Economics, University of Moratuwa, Sri Lanka, tsjayawickrama@gmail.com

${ }^{3}$ Department of Building Economics, University of Moratuwa, Sri Lanka, dgmelagoda92@gmail.com

${ }^{4}$ Department of Building Economics, University of Moratuwa, Sri Lanka, dulinirathnayake@gmail.com
} 
Shen, 2007; Langston et al., 2008; Bullen and Love, 2010, 2011; Langston, 2012; Hong and Chen, 2017) have studied on adaptive reuse of buildings, mainly focusing on implementation challenges, design strategies, decision-making and adaptive reuse potential of buildings. De Silva et al. (2017) conducted a study on strategies, challenges and barriers of adaptive reuse of buildings in Sri Lankan context. Yet, comprehensive research content is not found regarding decision-making on adaptive reuse of historic buildings (ARHB) in developing countries. This study seeks to address this gap by determining the critical decision-making factors for ARHB and, compatible and viable new uses for historic buildings in Sri Lanka.

\section{ADAPTIVE REUSE AS THE BEST ALTERNATIVE FOR INEFFECTIVE BUILDINGS}

The incorporation of historic conservation with environmental concerns has turned into an intrinsic component of an agenda to support sustainability (Bullen and Love, 2011). To promote sustainability, many buildings of notable cultural and historical values are being adapted and reused instead of being subjected to demolition as part of a wider reinvigoration strategy (Bullen and Love, 2011; Langston and Shen, 2007). Reusing an existing building not only increases the life of a building but also lower material, transport, energy consumption and pollution, thus making a significant contribution to sustainability (Love and Bullen, 2009). Douglas (2006), and Kohler and Yang (2007) have stated that costs of reusing buildings are lower than the equivalent costs of demolition when the related benefits, relative costs and constraints of reuse vs demolition and reconstruction are concerned. Bullen (2007) argues that even though adapted building may not entirely correspond with the performance of a new building, the shortfall should be balanced against the gains in social value. Adaptive reuse of buildings has a considerable part to play in sustainable development of communities, producing valuable community capital from unproductive properties, controlling sprawl and revitalizing existing neighbourhoods (Bullen, 2007).

\section{EXISTING MODELS FOR ADAPTIVE REUSE DECISION-MAKING}

Ball $(1989,2002)$ carried out a survey about vacant industrial premises in Stoke-on-Trent in UK and argued that identified characteristics of industrial property stock that were reoccupied or reused in comparison to vacant ones suggested the adaptive reuse potential of a building. Langston's model recognizes applicability of adaptive reuse of buildings in different countries and to various building typologies as well as when the planning for building's adaptive reuse should be commenced (Langston, 2012). The model took account of the current age and expected physical life of the building and requires an assessment of functional, economical, physical, social, technological and legal obsolescence which was believed to have reduced the useful life. Based on Langston et al.'s (2008) ARP model, Conejos et al. (2013) further developed an AdaptSTAR model which was a weighted checklist of design strategies, intended to consider adaptive reuse in the initial design process. But Hong and Chen (2017) indicated that the proposed model did not recognize the uniqueness of historic buildings of which the socio-cultural value might outweigh other aspects and the best intervention points might have already passed for many historic buildings. 
Furthermore, a group of researchers proposed a decision - making tool for selecting Office Building Upgrading Solutions (TOBUS) targeting office buildings in Europe to assist building owners and managers diagnose energy consumption, indoor environment quality, physical and functional obsolescence of office buildings; to estimate costs and elaborate refurbishment scenarios (Caccavelli and Gugerli, 2002). A similar tool, namely National Australian Built Environment Rating System (NABERS) was introduced to measure the environmental performance of existing residential and commercial office buildings during operation. However, both tools are targeted at individual buildings and do not take social, historical and artistic values of buildings into consideration (Hong and Chen, 2017). An Australian group of researchers proposed a decision-making model for adaptive reuse of buildings aimed at providing a point of reference to assist practitioners with making decisions regarding reuse or demolition in the Australian context (Bullen and Love, 2010, 2011). The model identified key issues related to adaptive reuse of buildings that need to be addressed by developers, policy makers and building owners during the design stage of projects to achieve more sustainable outcomes.

\section{THE EXTENT AND NATURE OF PHYSICAL CHANGE}

Numerous changes are required for adaptive reuse, the most dynamic form of preservation to be successful (Compton, 2005). Adaptive reuse projects may require certain materials to be reconstituted to retain the ambiance of the site (Smallwood, 2012). Aged materials provide the authenticity, credibility and sense of status to the building and community, required to create a unique civic character (Bullen and Love, 2010; Langston et al., 2007; Smallwood, 2012). The study of Kincaid (2003) identified two main types of physical changes that must be considered, namely, those to the external building fabric and those to the internal spaces and layout and developed four basic strategies for adaptation as shown in Figure 1.

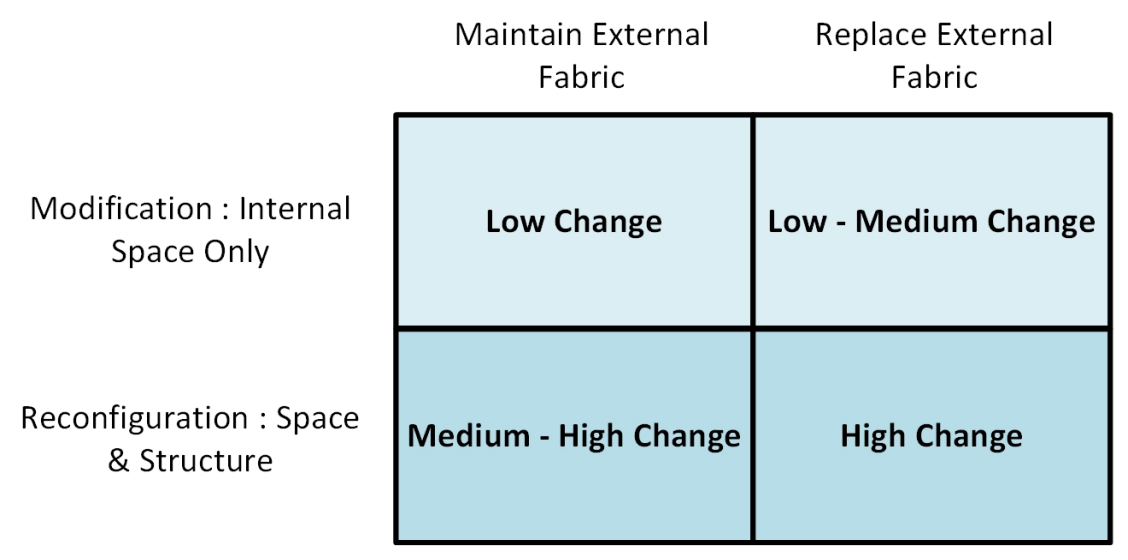

Figure 1: Types of physical change to buildings (Source: Kincaid, 2003)

\section{FACTORS AFFECTING ADAPTIVE REUSE DECISION- MAKING OF BUILDINGS}

Previous studies conducted on building adaptability have identified key building attributes in favour of adaptation (Wilkinson et al., 2009). Most influential factors for adaptive reuse decision-making of historic buildings are presented in Table 1, based on available literature. 
Table 1: Factors affecting adaptive reuse decision-making of buildings

\begin{tabular}{|c|c|}
\hline $\begin{array}{l}\text { ARHB Decision } \\
\text { Criteria }\end{array}$ & Relevant research study \\
\hline Structural Integrity & $\begin{array}{l}\text { Gann and Barlow (1996), Swallow (1997), Larssen and Bjorbery } \\
\text { (2004), Snyder (2005), Kersting (2006), Bullen and Love (2011), Hong } \\
\text { and Chen (2017) }\end{array}$ \\
\hline Residual Service Life & $\begin{array}{l}\text { Barras and Clark (1996), Ball (1999, 2002), Fianchini (2007), Bullen } \\
\text { and Love (2011) }\end{array}$ \\
\hline Internal Layout & $\begin{array}{l}\text { Gann and Barlow (1996), Swallow (1997), Fianchini (2007), Szarejko } \\
\text { and Trocka-Lesczynska (2007), Bullen and Love (2011), Hong and } \\
\text { Chen (2017) }\end{array}$ \\
\hline $\begin{array}{l}\text { Internal and External } \\
\text { Space }\end{array}$ & $\begin{array}{l}\text { Gann and Barlow (1996), Keymer (2000), Ball (2002), Larssen and } \\
\text { Bjorbery (2004), Szarejko and Trocka-Lesczynska (2007) Bullen and } \\
\text { Love (2011), Hong and Chen (2017) }\end{array}$ \\
\hline Functionality & $\begin{array}{l}\text { Gann and Barlow (1996), Fianchini (2007), Rawlinson and Harrison } \\
\text { (2009), Bullen and Love (2011), Wilkinson (2014), Manewa et al. } \\
\text { (2016) }\end{array}$ \\
\hline Location & $\begin{array}{l}\text { Bryson (1997), Ball (1999, 2002), Douglas (2006), Remoy and van der } \\
\text { Voordt (2007), Bullen and Love (2011), Hong and Chen (2017) }\end{array}$ \\
\hline Site condition & $\begin{array}{l}\text { Kincaid (2003), Larssen and Bjorbery (2004), Douglas (2006), } \\
\text { Highfield (2009), Bullen and Love (2011), Hong and Chen (2017) }\end{array}$ \\
\hline Surrounding condition & Bullen and Love (2011), Hong and Chen (2017) \\
\hline Infrastructure & $\begin{array}{l}\text { Gann and Barlow (1996), Ball (2002), Ellison and Sayce (2007), } \\
\text { Remoy and van der Voordt (2007), Hong and Chen (2017) }\end{array}$ \\
\hline Public Transport & Kincaid (2000), Bullen and Love (2011), Hong and Chen (2017) \\
\hline Tectonic Beauty & Ball (2002), Bullen and Love (2011), Hong and Chen (2017) \\
\hline Landscaping Quality & Bullen and Love (2011), Hong and Chen (2017) \\
\hline Economic Return & Ball (2002), Bullen and Love (2010, 2011), Hong and Chen (2017) \\
\hline Use Value & Bullen and Love (2011), Hong and Chen (2017) \\
\hline Marketability & Ball (2002), Bullen and Love (2011) \\
\hline Historical Value & $\begin{array}{l}\text { Brereton (1995), Ball (2002), Snyder (2005), Bullen and Love (2011), } \\
\text { Hong and Chen (2017) }\end{array}$ \\
\hline Cultural Value & $\begin{array}{l}\text { O’Donnell (2004), Myers and Wyatt (2004), Bullen and Love (2011), } \\
\text { Langston et al. (2008), Langston (2012), Hong and Chen (2017) }\end{array}$ \\
\hline $\begin{array}{l}\text { Facilitating Public } \\
\text { Education }\end{array}$ & Hong and Chen (2017) \\
\hline $\begin{array}{l}\text { Facilitating Social } \\
\text { Interaction }\end{array}$ & O’Donnell (2004), Langston et al. (2008), Hong and Chen (2017) \\
\hline Value Exhibition & Kincaid (2003), Hong and Chen (2017) \\
\hline Legislation & $\begin{array}{l}\text { Gann and Barlow (1996), Ball (2002), Snyder (2005), Shipley et al. } \\
\text { (2006), Kersting (2006), Highfield (2009), Bullen and Love (2011), } \\
\text { Hong and Chen (2017) }\end{array}$ \\
\hline
\end{tabular}




\section{ADAPTIVE REUSE OF HISTORIC BUILDINGS}

As pointed out by Pearce (2014), rather than just preserving buildings for their heritage and architectural significance, adaptive reuse allows buildings to be preserved and used as a way of life of those labelled 'ordinary people'. Unlike other preserving policies that are concerned with accurate restoration and limited change, adaptive reuse supports the idea of change instead of considering historic buildings as just an art object, making them a product of a whole socio-economic system (Mengüşoğlu and Boyacioğlu, 2016). Finding suitable alternative uses to preserve such buildings was further emphasized.

\subsection{DRIVERS AND BARRIERS FOR ADAPTIVE REUSE OF HISTORIC BUILDINGS}

Reuse of historic buildings does not necessarily avert displacement of native residents but may retain the social meaning of place to a certain extent (Hong and Chen, 2017). Rehabilitating existing spaces is much faster than reconstructing new spaces in the same floor area which will consequently reduce costs (Johnson, 1996). However, Ellison et al. (2007) and Ball (1999) argue that in some cases refurbishing an old building to a specific sustainable standard could be more expensive and may require a significant investment to renovate and maintain if its external fabric has begun to deteriorate or founded with severe structural problems.

The study of Yung and Chan (2012) identified several significant implementation challenges regarding ARHB. Uncertainty about economic viability, difficulty in achieving cost efficiency, hindrance of social inclusiveness due to accessibility, difficulty in establishing a sense of place and identity, continuity of local community life, overlooking the relationship between the historic building and the surrounding environment, ambiguities and difficulties in retaining historic setting, government policies and strategies (differences in granted lease periods from site to site and delay of timely completion of projects due to the use of government funding), effective and appropriate community engagement opportunities (difficulty in involving many stakeholders in every stage of the project since it takes a very long time to obtain a constructive consensus), inadequate transparency and efficiency for the adaptive reuse policy are the main implementation challenges identified. In addition, Bullen and Love (2011) indicated that older buildings have difficulties complying with building codes during adaptive reuse, especially in areas of parking allocation, fire protection and disabled access requirements. From a purely financial perspective, scarcity of land has made investors believe that given very high land values, replacement of existing buildings with new structures is the only way to make a reasonable profit from using the land (Langston et al., 2007; Shipley et al., 2006).

Despite these impediments, Pendlebury (2002) argues that historic buildings carry a market cachet. Shipley et al. (2006) identifies, heritage buildings to have a great marketing leverage. Langston et al. (2007) highlighted that many older buildings were soundly constructed using a range of quality materials, typically displaying a useful life well in excess of their modern counterparts. Furthermore, many older buildings deliver long term operational efficiencies as they employ massive construction in their external envelop that can reduce energy consumption in heating and cooling (Mine, 2013). Sociocultural benefits are usually given less priority as they are being difficult to measure (Bullen and Love, 2011). Therefore, ARHB should be assured in government policies to 
ensure the continuity of social life that contributes to the cultural significance and the diversity of the place.

\subsection{NEW USES OF Historic BUILDINGS}

Compared to new development, adaptive reuse projects are unique and require a creative process in overcoming building challenges to adapt for new uses (Shipley et al., 2006). When drawing up for possible adaptive reuse proposals, Langston and Shen (2007) stated that a series of relevant factors should be considered, including building structure, historical background, district characteristics, tourism attractiveness, transportation and laws regulating the use. Kincaid (2003) stressed that identification of all the major players involved in decision making and implementation of adaptive reuse projects is necessary to assess which uses are likely to be financially and functionally viable. Although it may appear that adaptability potential of buildings is mainly constrained by internal space configurations and structure, Kincaid (2003) argues that most buildings are physically capable for adaptation as wide variety of uses are not necessarily limited by the space needs of a significant range of human activities. To deal with the question of what use a certain building could be best adapted to when found obsolete for its original or previous use, physical and locational characteristics of buildings should be identified and compared with a set of characteristics that describe the needs of a usage (Kincaid, 2000; Langston and Shen, 2007).

According to Shipley et al. (2006), the viability of proposed new uses needs to be examined against three critical sets of criteria namely; functional and use viability, technical and physical viability, and financial and economic viability. The designers should consider both refurbishments and new work of which characteristics give the built asset the most robust set of feasible use options in the future that could make a significant contribution to sustainability of cities as they are developed and changed (Kincaid, 2000).

\subsection{Regulations CONCERNING AdAPTIVE REUSE OF Historic BUILDINGS IN SRI LANKA}

Buildings of historical or archaeological importance are governed under Antiquities Ordinance (1940) in Sri Lanka and are deemed to be the absolute property of the state, maintained by the archaeological department. According to Antiquities (amendment) Act (1998), "any specific monument which has existed or is believed to have existed for a period of not less than hundred years, shall be deemed to be an ancient monument". When it comes to regulations concerning adaptive reuse in Sri Lankan context, a detailed guideline exists for the Galle Fort area (Urban Development Authority, 2009). This development plan for Galle urban development area has detailed the historical background, physical settings, environmental characters, archaeological importance, land use, economic activities, infrastructure, proposed zoning plan, zoning regulations and boundaries for further development. Yet, legislation concerning historic buildings in Sri Lanka tend to be a lot less flexible. Work associated with demolition, alteration or extension of historic buildings are restricted to a great extent due to lack of leadership and encouragement by the government, making it difficult to embrace ARHB in Sri Lanka. 


\section{CONCEPTUAL FRAMEWORK}

The conceptual framework summarizes the literature findings of the study as illustrated in Figure 2. The findings include drivers and barriers for ARHB and why adaptive reuse is considered as a superior alternative to renovation, restoration, demolition and reconstruction. Conceptual framework depicts 22 factors affecting ARHB decision identified through literature. Further, the extent and nature of physical change to the existing building resulting from adaptive reuse has been identified.

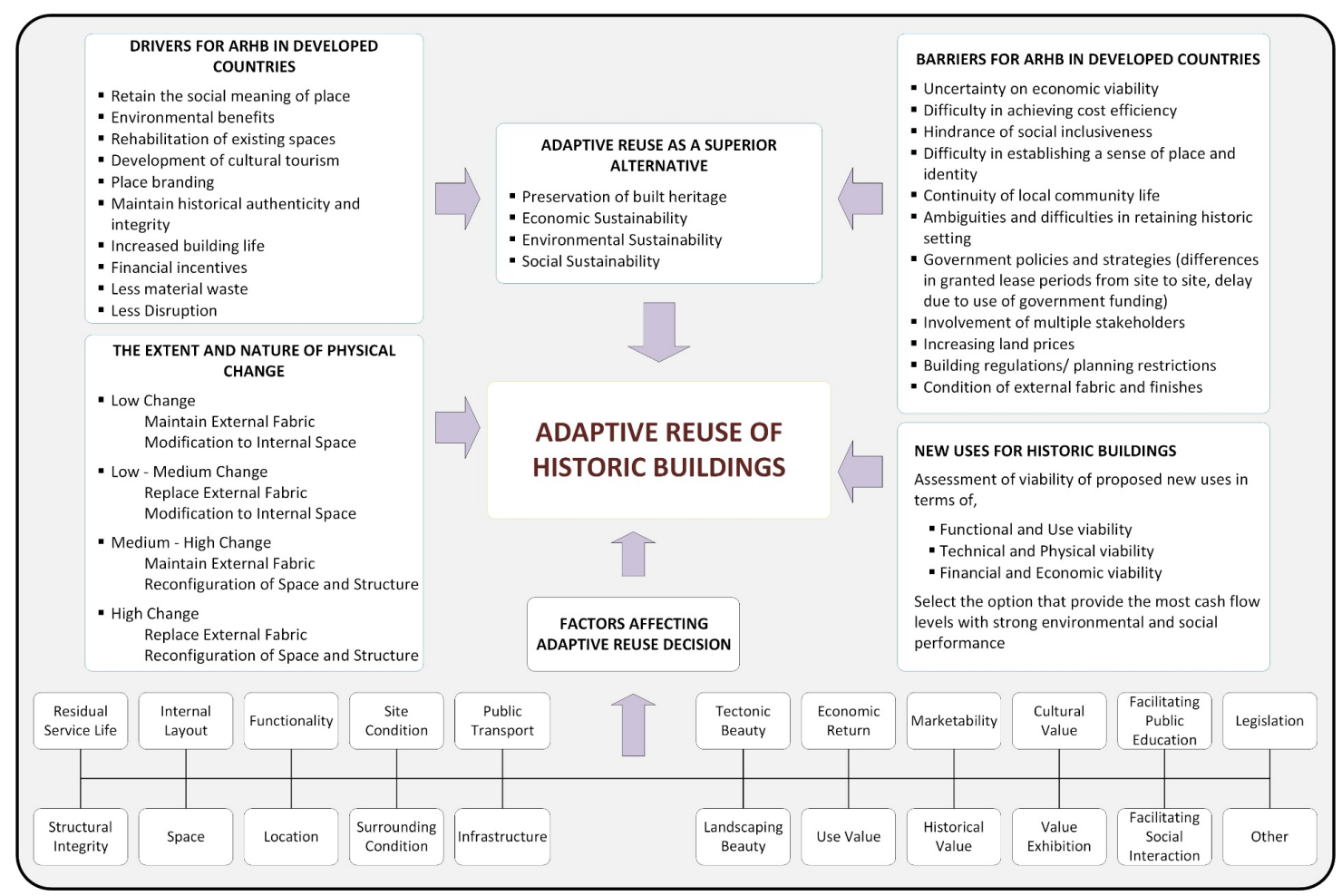

Figure 2: Conceptual framework

\section{CONCLUSIONS}

This study critically reviewed the adaptive reuse concept, alternative strategies for ineffective buildings, factors affecting the adaptive reuse of buildings and existing models concerning adaptive reuse decision-making in relation to previous research studies. Furthermore, drivers and barriers of ARHB were discussed, identifying adaptive reuse as a better alternative to obsolete buildings involved with many long-term benefits. Selecting a viable new use for a historic asset was revealed to be the most critical factor for the success of ARHB. As this is still a novel concept to Sri Lanka and most professionals and local authorities are yet unaware, this study concluded the need to develop a proper framework to guide adaptive reuse decision-making process concerning historic buildings in Sri Lanka.

\section{REFERENCES}

Antiquities (amendment) Act No. 24 of 1998. Sri Lanka: Department of Government Printing.

Antiquities Ordinance, 1940. Antiquities Ordinance of Sri Lanka (revised in 1956). Colombo: Government of Sri Lanka.

Ashworth, G., 2011. Preservation, conservation and heritage: Approaches to the past in the present through the built environment. Asian Anthropology, 10(1), pp.1-18. 
Ball, R., 1999. Developers, regeneration and sustainability issues in the reuse of vacant industrial buildings. Building Research and Information, 27(3), pp.140-148.

Ball, R.M., 1989. Vacant industrial premises and local development: A survey, analysis and policy assessment of the problem in Stoke-on-Trent. Land Development Studies, 6(2), pp.105-128.

Ball, R.M., 2002. Re use potential and vacant industrial premises: revisiting the regeneration issue in Stokeon-Trent. Journal of Property Research, 19(2), pp.93-110.

Barras, R. and Clark, P., 1996. Obsolescence and performance in the Central London office market. Journal of Property Valuation and Investment, 14(4), pp.63-78.

Brereton, C., 1995. The repair of historic buildings. London: English Heritage.

Bryson, J.R., 1997. Obsolescence and the process of creative reconstruction. Urban Studies, 34(9), pp.1439-1458.

Bullen, P.A. and Love, P.E., 2011. A new future for the past: a model for adaptive reuse decisionmaking. Built Environment Project and Asset Management, 1(1), pp.32-44.

Bullen, P., 2007. Adaptive reuse and sustainability of commercial buildings. Facilities, 25(1/2), pp.20-31.

Bullen, P.A. and Love, P.E., 2010. The rhetoric of adaptive reuse or reality of demolition: Views from the field. Cities, 27(4), pp.215-224.

Caccavelli, D. and Gugerli, H.T.O.B.U.S., 2002. TOBUS - a European diagnosis and decision-making tool for office building upgrading. Energy and Buildings, 34(2), pp.113-119.

Compton, B., 2005. Adaptive Reuse: Preservation's Next Argument. In: The Association of Collegiate Schools of Architecture Annual Meeting. Miami University, Ohio: ACSA Press, pp.128-136.

Conejos, S., Langston, C. and Smith, J., 2013. AdaptSTAR model: A climate-friendly strategy to promote built environment sustainability. Habitat International, 37, pp.95-103.

Conejos, S., Langston, C. and Smith, J., 2015. Enhancing sustainability through designing for adaptive reuse from the outset: A comparison of adaptSTAR and Adaptive Reuse Potential (ARP) models. Facilities, 33(9/10), pp.531-552.

De Silva, G.D.R., Perera, B.A.K.S. and Rodrigo, M.N.N., 2019. Adaptive reuse of buildings: the case of Sri Lanka. Journal of Financial Management of Property and Construction, 24(1), pp.79-96

Dean, B., Dulac, J., Petrichenko, K. and Graham, P., 2016. Towards zero-emission efficient and resilient buildings.: Global Status Report.

Douglas, J., 2006. Building adaptation. $2^{\text {nd }}$ ed. Routledge.

Ellison, L., Sayce, S. and Smith, J., 2007. Socially responsible property investment: quantifying the relationship between sustainability and investment property worth. Journal of Property Research, 24(3), pp.191-219.

Fianchini, M., 2007. Fitness for purpose: a performance evaluation methodology for the management of university buildings. Facilities, 25(3/4), pp.137-146.

Gann, D.M. and Barlow, J., 1996. Flexibility in building use: the technical feasibility of converting redundant offices into flats. Construction Management and Economics, 14(1), pp.55-66.

Highfield, D. and Gorse, C., 2009. Refurbishment and upgrading of buildings. Spon Press.

Hong, Y. and Chen, F., 2017. Evaluating the adaptive reuse potential of buildings in conservation areas. Facilities, 35(3/4), pp.202-219.

Johnson, A., 1996. Rehabilitation and re-use of existing buildings. In Mills E. D. Building maintenance and preservation: A guide to design and management, pp.209-230. Oxford: Architectural Press.

Kersting, J.M., 2006. Integrating past and present: the story of a building through adaptive reuse (Doctoral dissertation), University of Cincinnati.

Keymer, M.A., 2000. Design strategies for new and renovation construction that increase the capacity of buildings to accommodate change (Doctoral dissertation, Massachusetts Institute of Technology).

Kincaid, D., 2000. Adaptability potentials for buildings and infrastructure in sustainable cities. Facilities, 18(3/4), pp.155-161.

Kincaid, D., 2003. Adapting buildings for changing uses: guidelines for change of use refurbishment. Routledge. 
Kohler, N. and Yang, W., 2007. Long-term management of building stocks. Building Research and Information, 35(4), pp.351-362.

Langston, C. and Shen, L.Y., 2007. Application of the adaptive reuse potential model in Hong Kong: a case study of Lui Seng Chun. International Journal of Strategic Property Management, 11(4), pp.193-207.

Langston, C., 2008, November. The sustainability implications of building adaptive reuse. In CRIOCM 2008 International Research Symposium on Advancement of Construction Management and Real Estate, Beijing, China.

Langston, C., 2012. Validation of the adaptive reuse potential (ARP) model using iconCUR. Facilities, 30(3/4), pp.105-123.

Langston, C., Wong, F.K., Hui, E.C. and Shen, L.Y., 2008. Strategic assessment of building adaptive reuse opportunities in Hong Kong. Building and Environment, 43(10), pp.1709-1718.

Larssen, A.K. and Bjorbery, S., 2004, December. Users demand for functionality and adaptability of buildings-A model and a tool for evaluation of buildings. In Proceedings of the CIBW70 2004 Hong Kong International Symposium, Kowloon Shangri-La Hotel, Hong Kong, 7-8 December (pp. 167-176).

Love, P.E. and Bullen, P.A., 2009. Toward the sustainable adaptation of existing facilities. Facilities, 27(9/10), pp.357-367.

Manewa, A., Siriwardena, M., Ross, A. and Madanayake, U., 2016. Adaptable buildings for sustainable built environment. Built Environment Project and Asset Management, 6(2), pp.139-158.

Mengüşoğlu, N. and Boyacioğlu, E., 2016. Reuse of industrial built heritage for residential purposes in Manchester. METU Journal of the Faculty of Architecture, 30(1).

Mine, T., 2013. Adaptive re-use of monuments "restoring religious buildings with different uses". Journal of Cultural Heritage, 14(3), pp.S14-S19.

Myers, D. and Wyatt, P., 2004. Rethinking urban capacity: identifying and appraising vacant buildings. Building Research and Information, 32(4), pp.285-292.

O’Donnell, C., 2004. Getting serious about green dollars. Property Australia, 18(4), pp.1-2.

Pearce, D., 2014. Conservation Today: Conservation in Britain Since 1975. Routledge.

Pendlebury, J., 2002. Conservation and regeneration: complementary or conflicting processes? The case of Grainger Town, Newcastle upon Tyne. Planning Practice and Research, 17(2), pp.145-158.

Rawlinson, S. and Harrison, I., 2009. Cost model office refurbishment. Building Magazine, 10(3), pp.4853.

Remøy, H.T. and van der Voordt, T.J., 2007. A new life: conversion of vacant office buildings into housing. Facilities, 25(3/4), pp.88-103.

Shipley, R., Utz, S. and Parsons, M., 2006. Does adaptive reuse pay? A study of the business of building renovation in Ontario, Canada. International Journal of Heritage Studies, 12(6), pp.505-520.

Smallwood, C., 2012. The role of adaptive (re)use. In: PMI® Global Congress 2012. North America, Vancouver, British Columbia, Canada. Newtown Square: PA: Project Management Institute.

Snyder, G., 2005. Sustainability through Adaptive Reuse: The Conversion of Industrial Buildings. Thesis (Master of Architecture). University of Cincinnati.

Swallow, P., 1997. Managing unoccupied buildings and sites. Structural Survey, 15(2), pp.74-79.

Szarejko, W. and Trocka-Leszczynska, E., 2007. Aspect of functionality in modernization of office buildings. Facilities, 25(3/4), pp.163-170.

Urban Development Authority (2009). Development Plan for Galle Urban Development Area 2008 - 2025. Battaramulla, Sri Lanka: Urban Development Authority.

Wilkinson, S., 2014. How buildings learn: Adaptation of low grade commercial buildings for sustainability in Melbourne. Facilities, 32(7/8), pp.382-395.

Wilkinson, S.J., James, K. and Reed, R., 2009. Using building adaptation to deliver sustainability in Australia. Structural survey, 27(1), pp.46-61.

Yung, E.H. and Chan, E.H., 2012. Implementation challenges to the adaptive reuse of heritage buildings: Towards the goals of sustainable, low carbon cities. Habitat International, 36(3), pp.352-361. 